\title{
Changes in Imja Tsho in the Mount Everest region of Nepal
}

\author{
M. A. Somos-Valenzuela ${ }^{1}$, D. C. McKinney ${ }^{1}$, D. R. Rounce ${ }^{1}$, and A. C. Byers ${ }^{2}$ \\ ${ }^{1}$ Center for Research in Water Resources, University of Texas at Austin, Austin, Texas, USA \\ ${ }^{2}$ The Mountain Institute, Washington DC, USA
}

Correspondence to: D. McKinney (daene@aol.com)

Received: 2 April 2014 - Published in The Cryosphere Discuss.: 8 May 2014

Revised: 29 July 2014 - Accepted: 8 August 2014 - Published: 12 September 2014

\begin{abstract}
Imja Tsho, located in the Sagarmatha (Everest) National Park of Nepal, is one of the most studied and rapidly growing lakes in the Himalayan range. Compared with previous studies, the results of our sonar bathymetric survey conducted in September of 2012 suggest that its maximum depth has increased from 90.5 to $116.3 \pm 5.2 \mathrm{~m}$ since 2002 , and that its estimated volume has grown from $35.8 \pm 0.7$ to $61.7 \pm 3.7$ million $\mathrm{m}^{3}$. Most of the expansion of the lake in recent years has taken place in the glacier terminus-lake interface on the eastern end of the lake, with the glacier receding at about $52 \mathrm{~m} \mathrm{yr}^{-1}$ and the lake expanding in area by $0.04 \mathrm{~km}^{2} \mathrm{yr}^{-1}$. A ground penetrating radar survey of the Imja-Lhotse Shar glacier just behind the glacier terminus shows that the ice is over $200 \mathrm{~m}$ thick in the center of the glacier. The volume of water that could be released from the lake in the event of a breach in the damming moraine on the western end of the lake has increased to $34.1 \pm 1.08$ million $\mathrm{m}^{3}$ from the 21 million $\mathrm{m}^{3}$ estimated in 2002 .
\end{abstract}

\section{Introduction}

The rate of formation of glacial lakes in the Nepal Himalaya has been increasing since the early 1960s (Bolch et al., 2008; Watanabe et al., 2009; Bajracharya and Mool, 2009). Twenty-four new glacial lakes have formed, and 34 major lakes in the Sagarmatha (Mt. Everest) and Makalu Barun national parks of Nepal have grown substantially during the past several decades (Bajracharya et al., 2007). Accompanying this increase in the number and size of glacial lakes is an associated increase in the risk of glacial lake outburst flood (GLOF) events (Ives et al., 2010; Shrestha and Aryal, 2011). At least 12 of the new or growing lakes within the Dudh Koshi watershed of this region may be of concern, based on their rapid growth as evidenced by comparative time lapse, remotely sensed imagery over the past several decades (Bajracharya et al., 2007; Jianchu et al., 2007; Bolch et al., 2008; Watanabe et al., 2009).

GLOFs are the sudden release of a large amount of glacial lake water into a downstream watercourse, many orders of magnitude higher than the normal flow due to a moraine damming the lake (Carrivick and Rushmer, 2006). They can cause severe damage to downstream communities, infrastructure, agriculture, economic activities, and landscapes because of the sheer magnitude and power of the flood and debris flows produced (Bajracharya et al., 2007). The Khumbu region of Nepal (Fig. 1) is often mentioned as an area prone to GLOF events. The appearance and possible danger posed by new glacial lakes in this region has prompted national and regional groups to begin assessing engineering and nonengineering methods to mitigate increasing GLOF risks to communities, infrastructure, and landscapes downstream of the lakes (e.g., UNDP, 2013).

Imja-Lhotse Shar glacier is located in the Imja Khola watershed in the Khumbu region $\left(27.9^{\circ} \mathrm{N}, 86.9^{\circ} \mathrm{E}\right)$, about $9 \mathrm{~km}$ south of the summit of Mt. Everest. It is comprised of the Lhotse Shar glacier to the north and the Imja glacier to the east. The Amphu glacier appears to no longer contribute to the Imja-Lhotse Shar glacier. Several studies have used remotely sensed data to estimate glacier mass loss in the Everest area over the past few decades. Bolch et al. (2011) studied the mass change for 10 glaciers in the Khumbu region south and west of Mt. Everest, and found that the Imja-Lhotse Shar glacier exhibited the largest loss rate in the Khumbu region, $-0.5 \pm 0.09$ m w.e. $\mathrm{yr}^{-1}$ (meter water equivalent per year) for the period 1970-2007 and $-1.45 \pm 0.52 \mathrm{~m}$ w.e. $\mathrm{yr}^{-1}$ for 2002-2007. They noted that this large mass loss was due in part to enhanced ice 


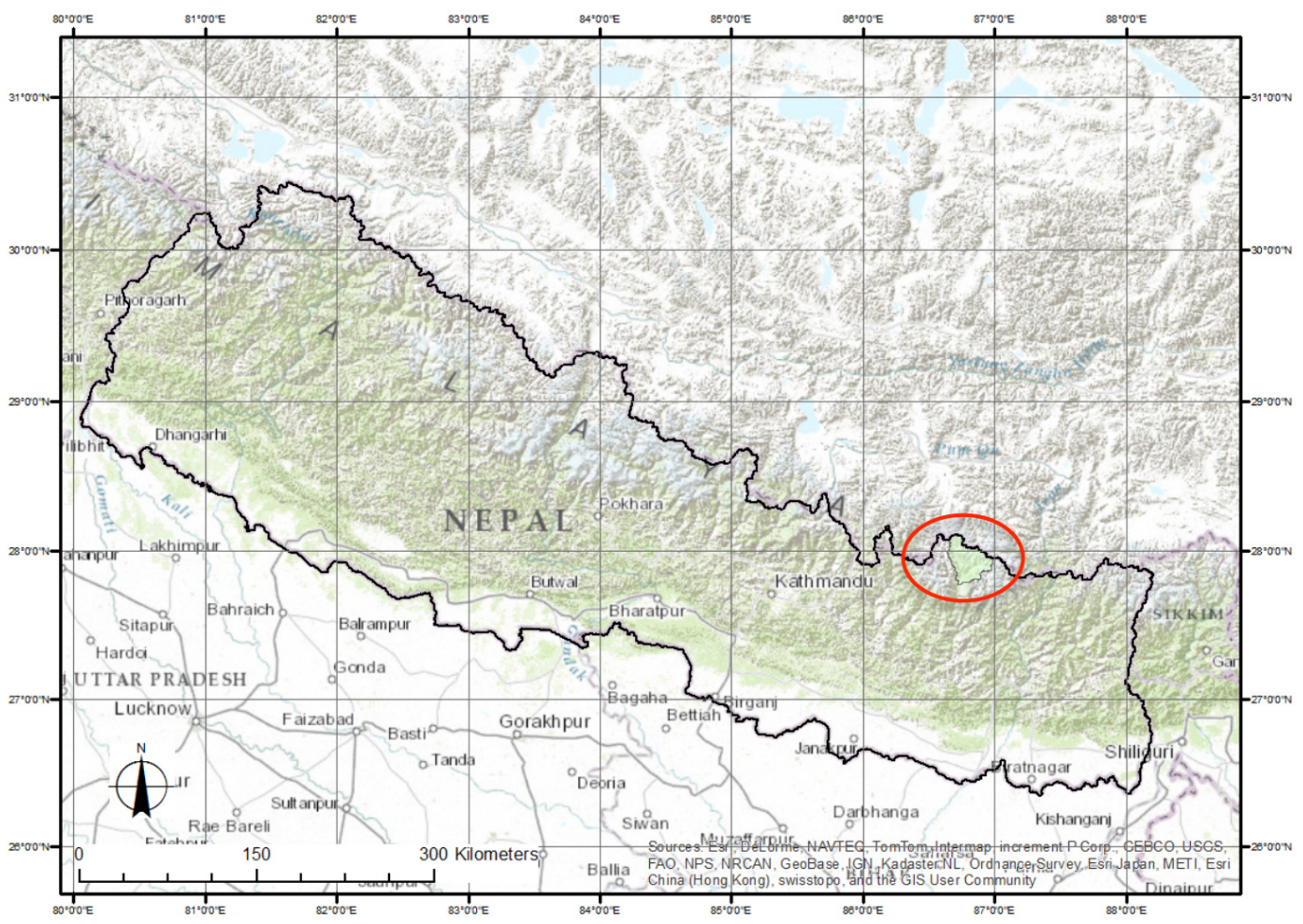

Figure 1. Location of the Khumbu region of Nepal. Source: ESRI, World Imagery (2014).

losses by calving into Imja Tsho. Nuimura et al. (2012) also report significant surface lowering of the glaciers of this area, including $-0.81 \pm 0.22 \mathrm{mw}$.e. $\mathrm{yr}^{-1}$ (19922008) and $-0.93 \pm 0.60 \mathrm{mw}^{2}$.e. $\mathrm{yr}^{-1}$ (2000-2008) for the Imja-Lhotse Shar glacier. Gardelle et al. (2013) reported $-0.70 \pm 0.52 \mathrm{~m}$ w.e. $\mathrm{yr}^{-1}$ (1999-2011), for the Imja-Lhotse Shar glacier. They note that for areas with growing proglacial lakes, their mass losses are slightly underestimated because they do not take into account the glacier ice that has been replaced by water during the expansion of the lake. The bathymetric survey reported here can help also to refine the mass balance estimate of the Imja-Lhotse Shar glacier because it will improve the quantification of these aqueous losses.

Hammond (1988), in one of the first studies in the region concerned with glacial lakes, identified 24 lakes and numerous other meltwater ponds in the Khumbu region in 1988. Most of these lakes began forming in the late 1950s to early 1960s, and have expanded considerably since then, especially the Imja Tsho (lake). For example, the 1963 Schneider map of the Everest region does not show a lake on the ImjaLhotse Shar glacier, but rather five small meltwater ponds on the surface near the glacier's terminus (Hagen et al., 1963). The expansion of Imja Tsho since the mid-1950s has been documented through the use of repeat oblique photography (Byers, 2007) and remote sensing (Mool et al., 2001).
A number of authors have discussed the details of Imja Tsho's development (Quincey et al., 2007; Bajracharya et al., 2007; Yamada, 1998; Watanabe et al., 2009; Ives et al., 2010; Lamsal et al., 2011). Imja Tsho is bounded to the east by the Imja-Lhotse Shar glacier, to the north and south by lateral moraines, and to the west by the moraine of the former glacier terminus. The lateral moraine troughs act as gutters, trapping debris derived from rockfall, snow avalanches, and fluvial transport (Hambrey et al., 2008). Imja Tsho is dammed by the $700 \mathrm{~m}$ wide by $600 \mathrm{~m}$ long, ice-cored, debriscovered, former glacier tongue through which water exits by means of an outlet lake complex (Watanabe et al., 1994, 1995). The former glacier tongue still contains ice, as clearly evidenced by outcrops of bare ice, ponds formed by meltwater from ice in the moraine, and traces of old ponds (Yamada and Sharma, 1993). The incision of the outlet channel complex has lowered the lake level by some $37 \mathrm{~m}$ over the last 4 decades (Watanabe et al., 2009; Lamsal et al., 2011). The outlet flow from the lake forms the river Imja Khola, which is a tributary of the Dudh Koshi river. It is likely that the outlet lake complex is evolving into a new arm of the lake (Benn et al., 2012). The bottom of Imja Tsho is most likely dead ice, given the observed frequency of subaqueous calving and presence of icebergs with apparent subaqueous origins, and the presumed melting of this ice caused the lake level to fall for several decades (Watanabe et al., 1995; Fujita et al., 2009). 
We conducted a sonar bathymetric survey of Imja Tsho and its outlet complex and a ground penetrating radar (GPR) survey of the Imja-Lhotse Shar glacier in September 2012. The purpose of this paper is to report on the results of those surveys and examine the changes in Imja Tsho volume and area. We rely on a combination of data collected in the field and remotely sensed data to make our analysis.

\section{Method}

\subsection{Lake area calculation}

Bathymetric surveys of Imja Tsho were conducted in April 1992 (Yamada and Sharma, 1993), April 2002 (Sakai et al., 2003), and September 2012 (this study). Landsat satellite imagery is used to compare the areal expansion of Imja Tsho with the changes in bathymetry. Unfortunately, Landsat images from the exact dates of the bathymetric surveys are not available, so the images selected are as close to the survey dates as possible. The images comprise a Landsat- 4 image from 4 July 1992 and Landsat-7 images from 4 October 2002 and 29 September 2012. The processing level of the Landsat images are all L1T, indicating that the images are all geometrically rectified using ground control points from the 2005 Global Land Survey in conjunction with the $90 \mathrm{~m}$ global DEM generated by the Shuttle Radar Topographic Mission (SRTM). The swipe visualization tool in PCI Geomatica 2013 was used with Landsat band 7 from each image to confirm that the images were properly co-registered. The co-registered images were used to compute changes in the areal extent of Imja Tsho.

The normalized differential water index (NDWI) (McFeeters, 1996) was used to semi-automatically compute the area of the lake. Bolch et al. (2008) found the area of Imja Tsho derived using the NDWI agreed well with a manual delineation performed by Bajracharya et al. (2007), thereby validating the use of the NDWI method. The NDWI was computed using Landsat bands 4 and 5. A threshold of zero was used to classify a pixel as water versus land. Large debris-covered icebergs near the calving front may cause pixels to be misclassified as land rather than water. These pixels are manually corrected in post-processing. Furthermore, at the calving front it can be difficult to distinguish the lake and icebergs from melt ponds located immediately behind the calving front. To prevent misclassification of the calving front, pixels classified as water that are not cardinally connected to the lake are classified as melt ponds. The perimeter of the lake, which is used to quantify uncertainty, is defined as any water pixel that has a land pixel in any cardinal or diagonal direction. The Landsat images have an image-to-image registration accuracy of $7.3 \mathrm{~m}$. The absolute geodetic accuracy is estimated to be $\sim 80 \mathrm{~m}$. When using NDWI we have a maximum error of $\pm 15 \mathrm{~m}$ for each pixel.

\subsection{Bathymetric survey}

Previous bathymetric surveys of Imja Tsho were conducted in 1992 (Yamada and Sharma, 1993) and 2002 (Sakai et al., 2003; Fujita et al., 2009). In 1992, measurements were taken at 61 points around the lake through holes drilled in the ice using a weighted line. In 2002, measurements were made at 80 uniformly spaced points on the lake using a weighted line. We conducted a bathymetric survey of Imja Tsho between 22 and 24 September 2012 using a Biosonic Habitat Echosounder MX sonar unit mounted on an inflatable raft. The BioSonics MX Echosounder (BioSonics, 2012) unit has an accuracy of $1.7 \mathrm{~cm} \pm 0.2 \%$ of depth, $0-100 \mathrm{~m}$ depth range, single frequency $(204.8 \mathrm{kHz})$ transducer with $8.5^{\circ}$ conical beam angle, and integrated DGPS with $<3 \mathrm{~m}$ positional accuracy (Garmin, 2009). Several transects were made around the lake with the sonar unit measuring the depth (Fig. 2).

For areas with depths greater than $100 \mathrm{~m}$, the equipment does not measure the depth but it still records the position of those points. To estimate the depth of the lake in these areas, we interpolate from the values of the shallower points. To achieve this, transects are established crossing the lake from north to south over these deep areas. The shape of the lake bottom along the transect from north to south is assumed to follow a parabolic shape fit to the measured points which are used to estimate the depths at the missing points.

During the survey, large icebergs blocked access to the eastern end of the lake. Robertson et al. (2012) found that ice ramps at the glacier end of glacial lakes tend to have slopes between 11 and $30^{\circ}$ and exhibit subaqueous calving. The level of knowledge of ice ramps in glacial lakes is limited, so it is difficult to determine ramp gradients exactly without detailed bathymetric information. Rather than using the slopes from Robertson et al. (2012), that are more applicable to the Tasman glacier area, the slopes have been changed to resemble the slopes measured at Imja Tsho in 1992 and 2002 by Sakai et al. (2005). Figure 3 shows a longitudinal dashed line in the lake following the 1992 and 2002 transect from the western shoreline of the lake to the eastern shoreline reported by Sakai et al. (2005). They found lake-bottom slopes near the eastern shoreline in 1992 to be $39^{\circ}$ in the first $100 \mathrm{~m}$ from the glacier and $12^{\circ}$ in the next $200 \mathrm{~m}$; in 2002 the slopes were found to be $32^{\circ}$ in the first $50 \mathrm{~m}, 20^{\circ}$ in the next $150 \mathrm{~m}$ and $12^{\circ}$ in the next $200 \mathrm{~m}$ (Sakai et al., 2005, Fig. 6, p. 77). In order to introduce this sloped behavior into the estimation of the lake bottom in the iceberg-obstructed area of 2012 and to take account of the uncertainty in the bottom slope, minimum and maximum slopes of the lake floor in front of the glacier terminus were used to approximate bounds for the lake volume in 2012 . The maximum slopes were $40^{\circ}$ for the first $100 \mathrm{~m}$ from the shoreline, $20^{\circ}$ for the next $150 \mathrm{~m}$, and $5^{\circ}$ for the last $150 \mathrm{~m}$, while the minimum slopes were 20,10 , and $2^{\circ}$, respectively. The slopes found by Sakai et al. (2005) are within these bounds. 


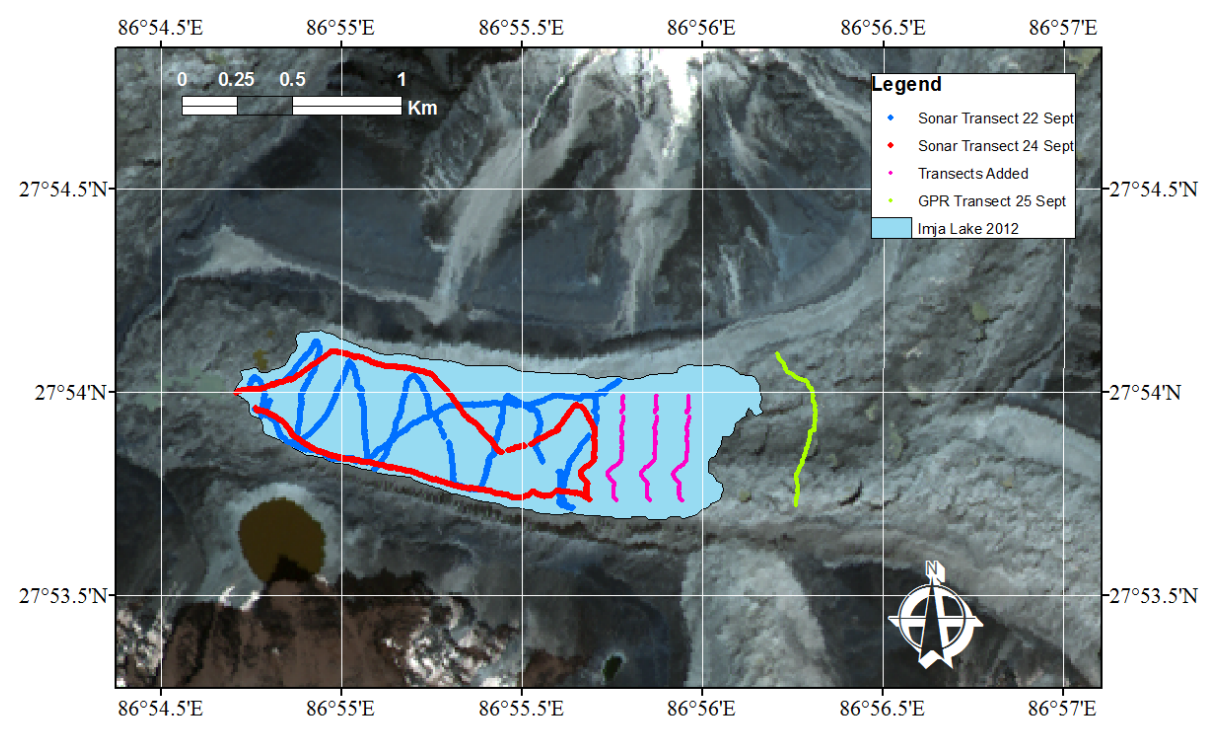

Figure 2. Sonar bathymetric survey transects at Imja Tsho, 22 September (red) and 24 (blue), the transects used to interpolate missing values (pink), and the GPR transect at Imja-Lhotse Shar glacier 25 September (green). The background is an ALOS image from 2008.

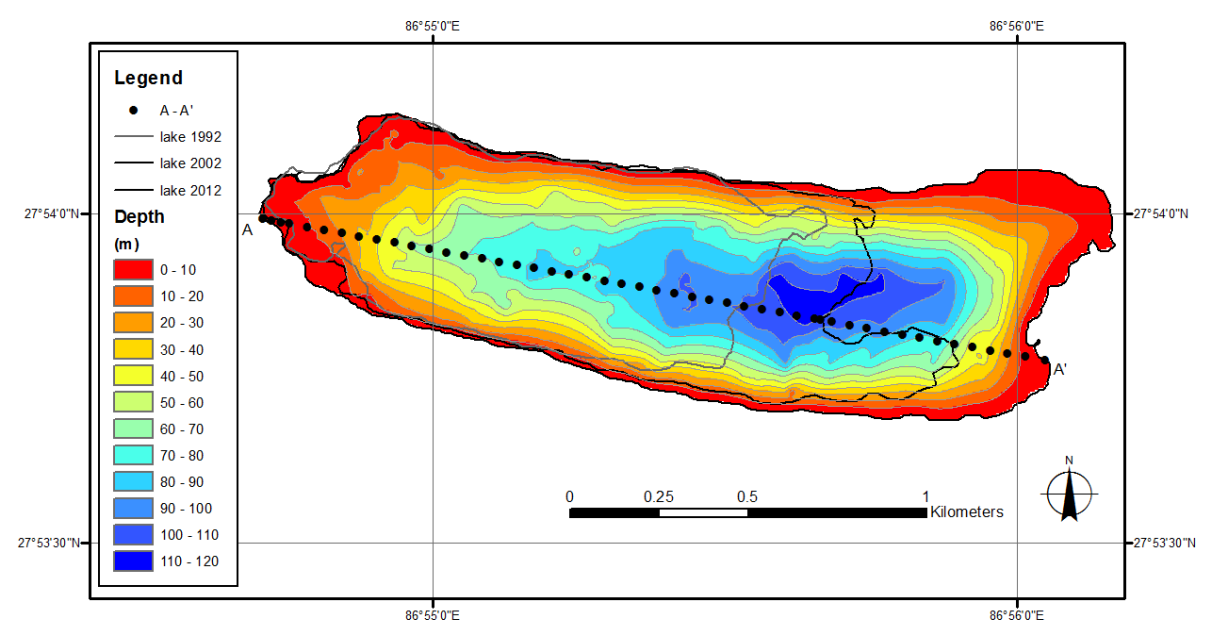

Figure 3. Bathymetric survey results from Imja Tsho in September 2012.

The uncertainty of the lake volume calculation is estimated using a range of depth for each point. In the areas where we were able to measure the depth of the lake we could directly calculate the maximum and minimum values using the error of sonar equipment $(1.7 \mathrm{~cm} \pm 0.2 \%$ of depth). The sonar instrument error applies to every point in the bathymetric survey. In the areas deeper than $100 \mathrm{~m}$, out of the sonar instrument range, the error is higher due to the interpolation calculations, and this error must be added to the instrument error. Quadratic interpolating functions were fit to the points of the 4 transects that have missing data (Fig. 2); for points deeper than $100 \mathrm{~m}$, interpolated values and $95 \%$ prediction bounds were calculated. The bounds were used to estimate maximum and minimum values associated with each interpolated value. Interpolated values less than $100 \mathrm{~m}$ were omitted, since the sonar instrument measured the depth at these points. This results in a cloud of points that cover the measured part of the lake, whereby each point has an associated maximum and minimum value. The points were interpolated to generate $5 \mathrm{~m}$ resolution maximum and minimum depth raster files, thus providing two values for each $25 \mathrm{~m}^{2}$. We assume that the depth in each cell follows a uniform probability distribution (USACE, 2003), which means that all the points within that range, maximum and minimum depth included, have the same probability of being the actual depth of the cell. In order to calculate the volume of the lake we used a Monte Carlo simulation with 2000 samples, which allows us to include the uncertainty in our measurement and assumptions; and calculate the expected value and standard deviation of the water volume. 
Finally, we have the uncertainty associated with the lake area calculation. The area calculation is performed using the NDWI procedure described in another section. The probability that the NDWI procedure will pick a pixel in the vicinity of the shoreline as lake or land is unknown, so we use a method similar to that just described for the lake volume to include the area calculation error. To estimate the maximum error in the lake area we consider that the lake outline could follow three different lines: the predicted lake outline, and outlines representing the maximum and minimum possible area. The lake volume is calculated for the three lake outlines using the procedure described above.

\subsection{Ground penetrating radar survey}

In order to better understand the structure of Imja-Lhotse Shar glacier in the proximity of the eastern end of Imja Tsho, a ground penetrating radar (GPR) survey was conducted and the transect of the survey is shown in (Fig. 2). The GPR survey was carried out on 25 September 2012 using a custom built, low-frequency, short-pulse, ground-based radar system. Gades et al. (2000) used a similar system on the debris-covered Khumbu glacier near Imja Tsho, but it was not configured for moving transects. The GPR transmitter was a Kentech Instruments Ltd. GPR pulser outputting $4 \mathrm{kV}$ signals with a $12 \mathrm{~V}$ power source. The receiving antenna is connected to an amplifier and a National Instruments USB-5133 digitizer whose output feeds into a LabView program for immediate processing in the field and correlation with GPS signals. Using a common offset, in-line deployment, the GPR pulses are transmitted and received through $10 \mathrm{MHz}$ weighted dipole antennae threaded inside climbing webbing. Post-processing steps performed on the data were topographic correction; pre-trigger points removed; deglitch; demean with smoothing of mean trace; detrend; bandpass filter; convert two-way travel time to depth using a radar velocity in ice of $167 \times 10^{6} \mathrm{~m} \mathrm{~s}^{-1}$; depth strip; and normalize by maximum absolute value.

\section{Results and discussion}

\subsection{Areal expansion of Imja Tsho}

The NDWI classifications of water pixels for the Landsat images are shown in white in Fig. 4. All the images have pixels identified as melt ponds and the 2012 image has debriscovered icebergs in the lake area, both of which are manually corrected for in post-processing. The derived lake areas for the 1992, 2002, and 2012 images are shown in Table 1. The 1992 lake area of $0.648 \mathrm{~km}^{2}$ agrees very well with the $0.60 \mathrm{~km}^{2}$ lake area measured by Yamada and Sharma (1993) measured in April 1992. The difference between these two measurements may be due to the lake expansion during the 1992 melt season and/or the error associated with the satellite image. The 2002 lake area of $0.867 \mathrm{~km}^{2}$ also agrees well
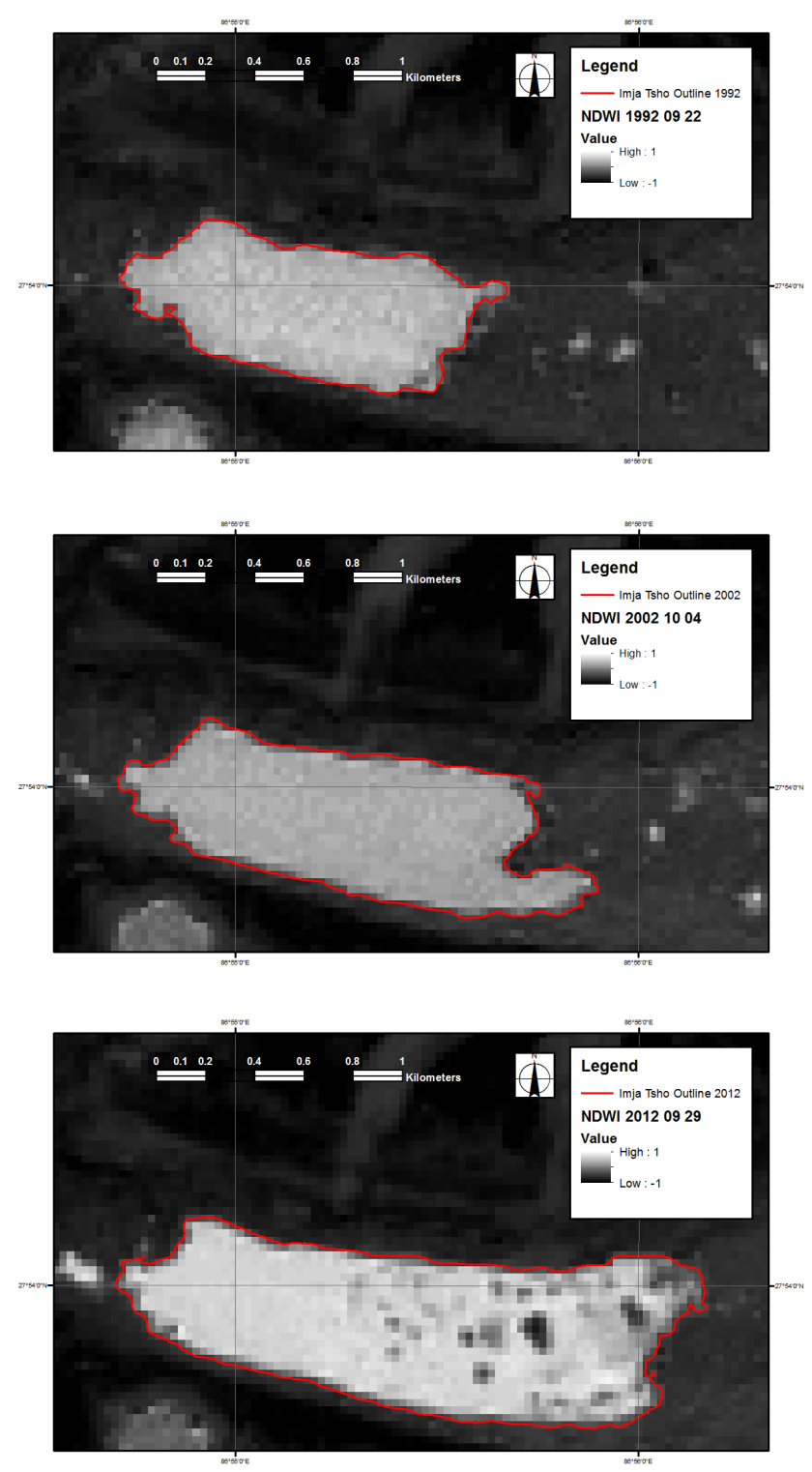

Figure 4. NDWI calculated from Landsat images for dates associated with bathymetric surveys in 1992 (top), 2002 (middle) and 2012 (bottom).

with the $0.86 \mathrm{~km}^{2}$ area that Sakai et al. (2003) derived, although the satellite imagery methods used in the referenced study were not described. The good agreement between the derived area and the previous studies demonstrates the effectiveness of using NDWI to outline the lake. The maximum error associated with these area measurements is the number of perimeter pixels multiplied by half the area of a pixel, since pixels on the perimeter that are more than half land would be classified as land. The maximum errors for the three images are also shown in Table 1. The areas of Imja Tsho over the last 50 years are listed in Table 3 and shown in Fig. 5. We witnessed extensive calving of the eastern glacier terminus, 
Table 1. Imja Tsho area expansion 1992-2012.

\begin{tabular}{llllllll}
\hline Year & $\begin{array}{l}\text { Icebergs } \\
\text { (no.) }\end{array}$ & $\begin{array}{l}\text { Melt } \\
\text { ponds } \\
\text { (no.) }\end{array}$ & $\begin{array}{l}\text { Lake } \\
\text { pixels } \\
\text { (no.) }\end{array}$ & $\begin{array}{l}\text { Perimeter } \\
\text { pixels } \\
(\text { no. })\end{array}$ & $\begin{array}{l}\text { Area } \\
\left(\mathrm{km}^{2}\right)\end{array}$ & $\begin{array}{l}\text { Max. } \\
\text { error } \\
\left(\mathrm{km}^{2}\right)\end{array}$ & $\begin{array}{l}\text { Decade } \\
\text { expansion } \\
\text { rate } \\
\left(\mathrm{km}^{2} \mathrm{yr}^{-1}\right)\end{array}$ \\
\hline $1992^{1}$ & & & & & 0.60 & & \\
$1992^{3}$ & 0 & 12 & 720 & 162 & 0.648 & 0.073 & \\
$2002^{2}$ & & & & & 0.868 & & 0.026 \\
$2002^{3}$ & 0 & 28 & 963 & 202 & 0.867 & 0.091 & 0.022 \\
$2012^{3}$ & 15 & 2 & 1397 & 231 & 1.257 & 0.104 & 0.039 \\
\hline
\end{tabular}

${ }^{1}$ Yamada and Sharma (1993)

${ }^{2}$ Fujita et al. (2009)

${ }^{3}$ This study

Table 2. Comparison of Imja Tsho 2012 Bathymetric survey results with previous studies. The 2012 volume and average depth uncertainty are $95 \%$ confidence bounds from the Monte Carlo sampling result. Maximum depth uncertainty is calculated from the $95 \%$ prediction bounds.

\begin{tabular}{lllll}
\hline Study & $\begin{array}{l}\text { No. of } \\
\text { points }\end{array}$ & $\begin{array}{l}\text { Volume } \\
\left(10^{6} \mathrm{~m}^{3}\right)\end{array}$ & $\begin{array}{l}\text { Ave. } \\
\text { depth }(\mathrm{m})\end{array}$ & $\begin{array}{l}\text { Max. } \\
\text { depth }(\mathrm{m})\end{array}$ \\
\hline $1992^{1}$ & 61 & 28.0 & 47.0 & 98.5 \\
$2002^{2}$ & 80 & $35.8 \pm 0.7$ & 41.6 & 90.5 \\
$2012^{3}$ & 10020 & $61.7 \pm 3.7$ & $48.0 \pm 2.9$ & $116.3 \pm 5.2$ \\
\hline
\end{tabular}

1 Yamada and Sharma (1993)

2 Sakai et al. (2003)

3 This study

estimated at more than $200 \mathrm{~m}$ of ice loss, between May and September of 2012, as indicated in Fig. 4 (bottom).

We can consider similar glacial lakes in the Nepal Himalaya. The lakes Imja Tsho, Tsho Rolpa and Thulagi are somewhat similar in that they are all moraine-dammed, still in contact with their feeding glaciers, and have been expanding up-glacier through glacial retreat and calving in the past few decades. Imja Tsho has been expanding significantly at a rate of $0.039 \mathrm{~km}^{2} \mathrm{yr}^{-1}$ (Table 1) and the glacier terminus has been retreating at a rate of $52.6 \mathrm{~m} \mathrm{yr}^{-1}$ (Table 4). The expansion of Tsho Rolpa has been minimal in the past decade (ICIMOD, 2011). The rate of expansion of Thulagi Lake is appreciably slower at $0.0129 \mathrm{~km}^{2} \mathrm{yr}^{-1}$ and retreating at a rate of $40.7 \mathrm{~m} \mathrm{yr}^{-1}$ (1993-2009; ICIMOD, 2011). The volume of Tsho Rolpa is increasing by an average of $0.26 \mathrm{~m}^{3} \mathrm{yr}^{-1}$ (ICIMOD, 2011), Thulagi by $0.5 \times 10^{6} \mathrm{~m}^{3} \mathrm{yr}^{-1}$, (ICIMOD, 2011) and Imja by $2.59 \times 10^{6} \mathrm{~m}^{3} \mathrm{yr}^{-1}$.

\subsection{Bathymetric survey}

A contour map of the depth of the bottom of Imja Tsho derived from the sonar measurements is shown in (Fig. 3). Water depths of $20-60 \mathrm{~m}$ were measured near the western edge

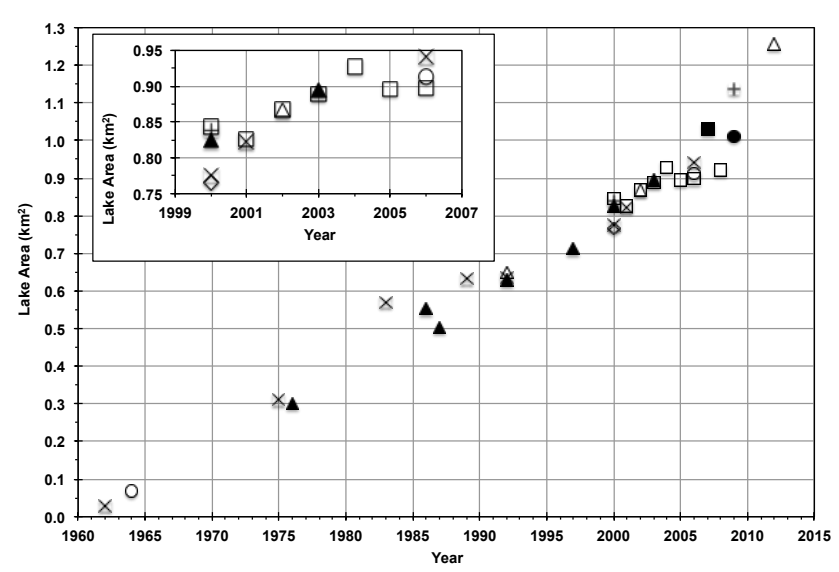

Figure 5. Imja Tsho area expansion 1962-2012. Source: Bajracharya et al. (2007) - x; Lamsal et al. (2011) - O; this study $\triangle$; Bolch et al. (2008) - $\diamond$; Gardelle et al. (2011) - +; Fujita et al. (2009) - $\square$; Watanabe et al. (2009) - black $\square$; ICIMOD (2011) black O; Sulzer and Gspurning (2009) - black $\triangle$.

of the lake (outlet end) and 30-100+ m deep near the eastern (glacier) end of the lake. Thick iceberg coverage on the eastern end of the lake prevented transects from being performed up to the calving front. Areas deeper than $100 \mathrm{~m}$ were interpolated from the surrounding values as described below. Apparently, the lake bottom has continued to lower as the ice beneath the lake has melted.

The bathymetric survey results are reported in Table 2, and they show that Imja Tsho has grown considerably over the last two decades. For example, the maximum depth measured in 2002 was $90.5 \mathrm{~m}$ (Sakai et al., 2007), compared with a depth of $116.3 \pm 5.2 \mathrm{~m}$ in the 2012 survey. As a result of the lake expansion and deepening, the estimated volume of water in the lake nearly doubles from the 2002 estimate, i.e., from $35.8 \pm 0.7$ million $\mathrm{m}^{3}$ in 2002 to $61.7 \pm 3.7$ million $\mathrm{m}^{3}$ in 2012. In calculating the uncertainty associated with this volume, we considered the error in the depth measurements, and in the slope of the ice ramp, but not in the lake area. 
Table 3. Imja Tsho area expansion 1962-2012.

\begin{tabular}{|c|c|c|c|}
\hline Year & $\begin{array}{l}\text { Area } \\
\left(\mathrm{km}^{2}\right)\end{array}$ & $\begin{array}{l}\text { Uncertainty } \\
\left(\mathrm{km}^{2}\right)\end{array}$ & Reference \\
\hline 1962 & 0.028 & & Bajracharya et al. (2007) \\
\hline 1964 & 0.068 & & Lamsal et al. (2011) \\
\hline 1975 & 0.310 & & Bajracharya et al. (2007) \\
\hline 1976 & 0.301 & & Sulzer and Gspurning (2009) \\
\hline 1983 & 0.569 & & Bajracharya et al. (2007) \\
\hline 1986 & 0.555 & & Sulzer and Gspurning (2009) \\
\hline 1987 & 0.505 & & Sulzer and Gspurning (2009) \\
\hline 1989 & 0.633 & & Bajracharya et al. (2007) \\
\hline 1992 & 0.631 & & Sulzer and Gspurning (2009) \\
\hline 1992 & 0.636 & & Bajracharya et al. (2007) \\
\hline 1992 & 0.648 & 0.073 & This study \\
\hline 1997 & 0.712 & & Sulzer and Gspurning (2009) \\
\hline 2000 & 0.766 & & Bolch et al. (2008) \\
\hline 2000 & 0.775 & & Bajracharya et al. (2007) \\
\hline 2000 & 0.824 & & Sulzer and Gspurning (2009) \\
\hline 2000 & 0.838 & 0.263 & Gardelle et al. (2011) \\
\hline 2000 & 0.844 & 0.036 & Fujita et al. (2009) \\
\hline 2001 & 0.824 & & Bajracharya et al. (2007) \\
\hline 2001 & 0.827 & 0.040 & Fujita et al. (2009) \\
\hline 2002 & 0.867 & 0.091 & This Study \\
\hline 2002 & 0.868 & 0.037 & Fujita et al. (2009) \\
\hline 2003 & 0.889 & 0.039 & Fujita et al. (2009) \\
\hline 2003 & 0.894 & & Sulzer and Gspurning (2009) \\
\hline 2004 & 0.928 & 0.041 & Fujita et al. (2009) \\
\hline 2005 & 0.896 & 0.042 & Fujita et al. (2009) \\
\hline 2006 & 0.897 & 0.041 & Fujita et al. (2009) \\
\hline 2006 & 0.913 & & Lamsal et al. (2011) \\
\hline 2006 & 0.941 & & Bajracharya et al. (2007) \\
\hline 2007 & 1.030 & & Watanabe et al. (2009) \\
\hline 2008 & 0.920 & 0.036 & Fujita et al. (2009) \\
\hline 2009 & 1.012 & & ICIMOD (2011) \\
\hline 2009 & 1.138 & 0.328 & Gardelle et al. (2011) \\
\hline 2012 & 1.257 & 0.104 & This study \\
\hline
\end{tabular}

Table 4. Retreat of Imja-Lhotse Shar glacier for 1992-2012 based on Landsat images.

\begin{tabular}{lllll}
\hline Period & \multicolumn{3}{c}{ Retreat } & \multirow{2}{*}{$\begin{array}{l}\text { Rate } \\
\left(\mathrm{m} \mathrm{yr}^{-1}\right)\end{array}$} \\
\cline { 2 - 4 } & $\begin{array}{l}\text { Average } \\
(\mathrm{m})\end{array}$ & $\begin{array}{l}\text { Std. dev. } \\
(\mathrm{m})\end{array}$ & $\begin{array}{l}\text { Max. error } \\
(\mathrm{m})\end{array}$ \\
\hline $1992-2002$ & 316 & 201 & 30 & 31.6 \\
$2002-2012$ & 526 & 231 & 30 & 52.6 \\
$1992-2012$ & 861 & 83 & 30 & 43.0 \\
\hline
\end{tabular}

Using the lake area uncertainty calculation method described above, the differences in the volume calculation results using the expected, maximum and minimum lake outlines are on the order of one-half a standard deviation; therefore the error associated with the area estimate is considered negligible and it is not included. The accuracy of the 1992 data are

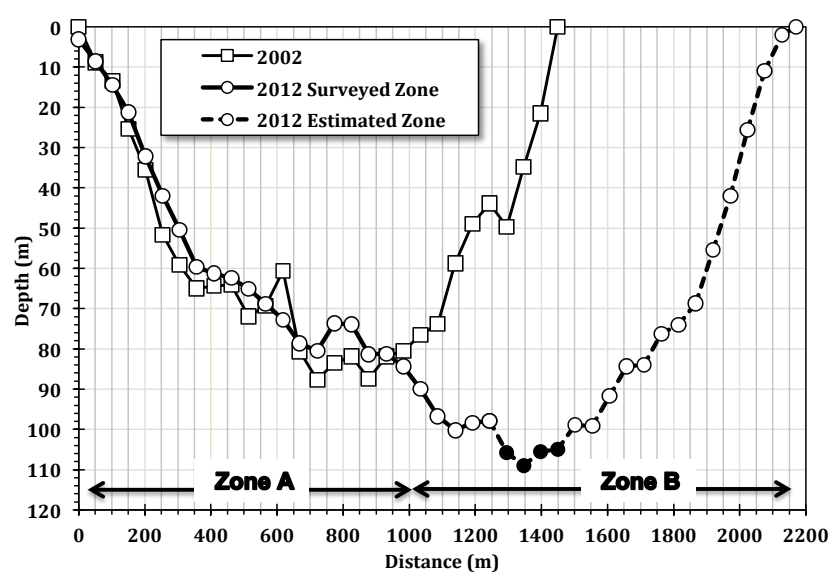

Figure 6. Cross section A-A' of the 2012 bathymetric survey for Imja Tsho compared to the 2002 survey. The solid indicates surveyed points and dashed line indicates estimated points. The filled circle markers indicate points deeper than $100 \mathrm{~m}$ where interpolation was used.

unknown; however, Fujita et al. (2009) estimated the uncertainty of the 2002 data to be \pm 0.7 million $\mathrm{m}^{3}$ by assuming the depth measurement error to be $0.5 \mathrm{~m}$. The volume of the lake in 2012 was $72 \%$ larger than in 2002, increasing at an average annual rate of 2.58 million $\mathrm{m}^{3} \mathrm{yr}^{-1}$. Compared to the prior surveys, the results show that the eastern section of the lake has deepened over the last decade (2002-2012) as the ice beneath has melted, with the average depth increasing by $0.86 \mathrm{~m} \mathrm{yr}^{-1}$. In the same period, the maximum depth has increased $28.5 \%$, or an annual rate of $2.58 \mathrm{~m} \mathrm{yr}^{-1}$.

Figure 6 shows the 2012 bathymetric survey results along section A-A' from Fig. 3, along with those of the 2002 survey (Sakai et al., 2003, Fig. 4, p. 559), indicating an eastward expansion of the lake, rapid retreat of the glacier ice cliff and the subaqueous melting that has taken place. The data from the 2002 survey (location and depth) were provided to us by the authors (K. Fujita, personal communication, 14 July 2014) and can be depicted in Fig. 6 by assuming that the lake surface has not changed since 2002. This assumption is reasonable as various studies have shown that the level of the lake has not changed significantly since 2002 (Sakai et al., 2007; Lamsal et al., 2011; Fujita et al., 2009).

Two distinct zones of Imja Tsho with different depths are illustrated in Fig. 6: zone A, 0-1000 m (western part), and zone B, 1000-2100 m (eastern part). The exact separation between these two zones is unknown, but it is estimated from the bathymetric data to occur at about $1000 \mathrm{~m}$ on Fig. 6. Reasons for the differences in depth between the two zones are not entirely clear, but may be related to the presence or nonpresence of ice at the lake bottom. That is, a lack of dead ice at the bottom of zone A would arrest all further deepening, while the presence of ice at the bottom of zone B would account for its continued deepening. This might also be due to a thick debris cover on the ice at the bottom of zone A. 
When the lake grew to form the western part (zone A), the growth rate was much smaller; therefore, more debris might have deposited on the lake bottom. Later, when zone B was formed, the rapid growth may not have resulted in thick debris to form on the lake bottom.

\subsection{Retreat of Imja-Lhotse Shar glacier}

The areal expansion of Imja Tsho is primarily in the eastward (up-glacier) direction due to the retreat of the calving front. The calving front was defined in the NDWI image processing as the last pixel in each row that has a lake pixel to its left and a land pixel to its right. A problem arises in the southern-most calving front pixels in which a calving front pixel is defined in a later image, but is not defined in an earlier image because the lake's width expanded. In this circumstance, which occurs three times between the 1992 and 2002 images and two times between the 2002 and $2012 \mathrm{im}$ ages, the calving front pixel for the older image is considered equal to the closest calving front pixel. The expansion rate for a row may then be computed as the difference between calving front pixels within a given row. The maximum error in this expansion rate estimate is one pixel. The average retreat distances for 1992-2002, 2002-2012, and 1992-2012 are shown in Table 4. From 2002 to 2012 the retreat greatly increased to $526 \mathrm{~m}\left(52.6 \mathrm{~m} \mathrm{yr}^{-1}\right)$. The corresponding standard deviations are large due to the calving front having an arm-like shape in 2002, which caused a non-uniform rate of retreat. The overall expansion rate from 1992 to 2012 was $43.0 \mathrm{~m} \mathrm{yr}^{-1}$.

Several other investigations have considered the retreat rate of Imja glacier and can be compared to our results. Based on a simple mass balance of glacial frontal change, Sakai et al. (2005; citing Yabuki, 2003) found the retreat rate to be $43 \mathrm{~m} \mathrm{yr}^{-1}$ for an unspecified period, which is higher than the value of $31.6 \pm 3 \mathrm{~m} \mathrm{yr}^{-1}$ the same period reported in Table 4; however, for the period 1992-2012 our results show an identical rate of $43.0 \pm 3 \mathrm{~m} \mathrm{yr}^{-1}$ (Table 4). Watanabe et al. (2009) found a rate of $48 \mathrm{~m} \mathrm{yr}^{-1}$ for the period 1997-2007, which is somewhat lower than $52.6 \pm 3 \mathrm{~m} \mathrm{yr}^{-1}$ for $2002-2012$ reported in Table 4.

\subsection{Drainable water from Imja Tsho}

Using the data reported above, we calculated the volume of water that could possibly drain from the lake for various levels of the lake surface. In the event of a breach of the former glacier terminus, water may not drain from the lake all at once and the timing or the hydrograph of the drainage is important in order to estimate the critical water volume that might cause serious damage downstream. However, detailed calculation of the volume and timing of discharge in the event of a breach of Imja Tsho requires extensive numerical simulations and is beyond the scope of this paper. Due to the continued areal expansion of the lake, there is an increasing

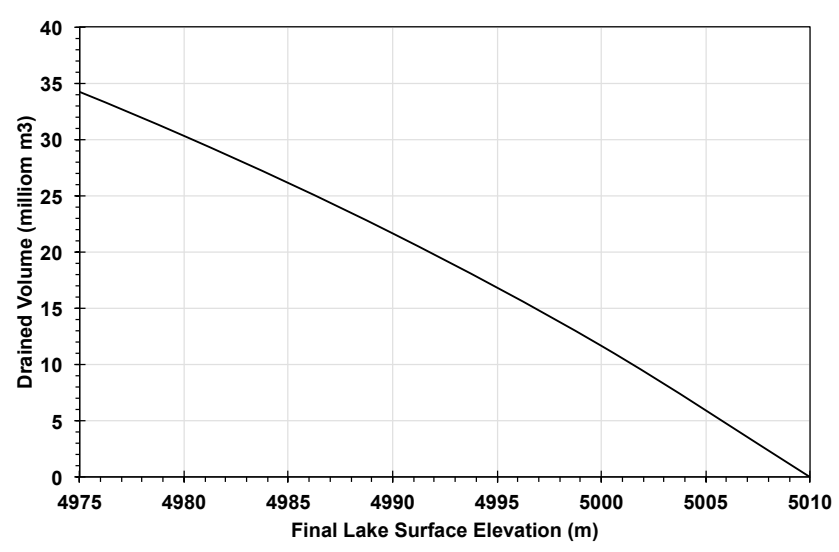

Figure 7. Potentially drained volume from Imja Tsho versus lake surface elevation.

amount of water that could drain from the lake in the event of a breach; however, this does not necessarily mean that there is an increased probability of occurrence of such an event.

Figure 7 shows the resulting drainage volume for various lake elevations. The maximum amount of water that could be released from the lake is $34.1 \pm 1.08$ million $^{3}$, if the lake surface elevation decreases from 5010 to $4975 \mathrm{~m}$ (the elevation of the valley floor below the lake). In a previous (2002) estimate, this volume was 20.6 million $\mathrm{m}^{3}$ (Sakai et al., 2007). The 2012 estimate is $40.5 \%$ larger than the 2002 value. This level of potential drainage water is a rough estimate and would require a complete collapse of damming moraine, which may be unlikely since Imja Tsho is dammed by a wide moraine $(>500 \mathrm{~m}$ ). Fujita et al. (2013) note that for Himalayan glacial lakes, if the damming moraine is wide enough or the height difference between the lake surface and the downstream valley is small enough, such a lake is unlikely to cause a GLOF. The relative height between lake surface and the base of moraine is not precisely known by land survey techniques. However, others have discussed the topography around the lake. The lake surface has lowered gradually over the past three decades (Lamsal et al., 2011) to a stable level of 5009-5010 $\mathrm{m}$ and the lake surface elevation is generally acknowledged to have been stable at about $5010 \mathrm{~m}$ for over a decade (Fujita et al., 2009; Lamsal et al., 2011).

Fujita et al. (2013) proposed an index method for characterizing potential flood volume (PFV) from glacial lakes in the Himalaya. The method is based on the depression angle between the lake water surface and any point within $1 \mathrm{~km}$ downstream. The potential lowering height $\left(H_{\mathrm{p}} \mathrm{m}\right)$ is the level that the lake must be lowered to so that the depression angle will be $10^{\circ}$. PFV is defined as

$\mathrm{PFV}=\operatorname{minimum}\left[H_{\mathrm{p}} ; D_{\mathrm{m}}\right] \cdot A$,

where $H_{\mathrm{p}}$ is the potential lowering height, $D_{\mathrm{m}}$ is the mean depth (m) and $A$ is the area $\left(\mathrm{km}^{2}\right)$ of the lake, respectively. 
Table 5. PFV calculations for Imja Tsho considering three starting points on the lake or outlet.

\begin{tabular}{lrrrr}
\hline & \multicolumn{3}{c}{ Calculation starting location } & \\
\cline { 2 - 4 } & Lake & Outlet middle & Outlet end & $\begin{array}{r}\text { Reduce } \\
\text { to } 10^{\circ}\end{array}$ \\
\hline Distance $(\mathrm{m})$ & 641 & 364 & 150 & 150 \\
Height $(\mathrm{m})$ & 35 & 35 & 35 & 26 \\
$\begin{array}{l}\text { Depression angle } \\
(\text { degrees })\end{array}$ & 3.1 & 5.5 & 13.5 & 10.0 \\
$A\left(\mathrm{~km}^{2}\right)$ & & & & \\
$H_{\mathrm{p}}(\mathrm{m})$ & & & & 1257 \\
PFV $\left(\right.$ million $\left.\mathrm{m}^{3}\right)$ & & & 9 & 11.3 \\
\hline
\end{tabular}

One of the difficulties in applying this method at Imja Tsho is defining the point at the lake from which to start the calculation. We considered three starting points for the PFV calculations: the western end of the main lake; midway from the main lake to the end of the outlet; and the end of the outlet (Table 5). We assumed the elevation of the lake and outlet are $5010 \mathrm{~m}$ and the downstream point is located where the outlet stream enters the valley below the moraine at $4975 \mathrm{~m}$. If the starting location is at the end of the lake outlet, then $\mathrm{PFV}=11.3$ million $\mathrm{m}^{3}$, but starting from the other locations results in a PFV $=0$. Certainly, the first case is a maximum one and can only occur if there is a complete collapse of the moraine. Fujita et al. (2013) imply that lowering the lake level to the point where the depression angle is less than $10^{\circ}$ may reduce this risk, which would require lowering the lake $9 \mathrm{~m}$ and removing 11.3 million $\mathrm{m}^{3}$ of water from the lake. This would represent a minimum level of lake lowering, since the PFV does not consider the condition of the moraine or possible breach-triggering mechanisms. It is possible that the end-of-outlet complex should not be used in the calculations because it does not properly take into account the width of the moraine. Fujita et al. (2013) calculated a PFV of zero for Imja Tsho (because $H_{\mathrm{p}}=0<D_{\mathrm{m}}$ ), indicating that it that is reasonably safe at that time. They note that future lowering of the moraine dam may possibly result in future changes to the lakeshore downstream (Fujita et al., 2009); therefore, continuous monitoring of such large-scale lakes is required. Thus, understanding the bathymetry of these large glacial lakes is very important.

\subsection{GPR survey of Imja-Lhotse Shar glacier}

Figure 8 shows the results of the GPR survey for the transect across the Imja-Lhotse Shar glacier from north to south using a $10 \mathrm{Mhz}$ antenna and assuming a velocity of propagation through the ice of $167 \times 10^{6} \mathrm{~m} \mathrm{~s}^{-1}$. The thickness of the glacier varies from $40-60 \mathrm{~m}$ near the lateral moraines to over $200 \mathrm{~m}$ in the center of the glacier. The implications of the glacier thickness and present lake depth are discussed below.

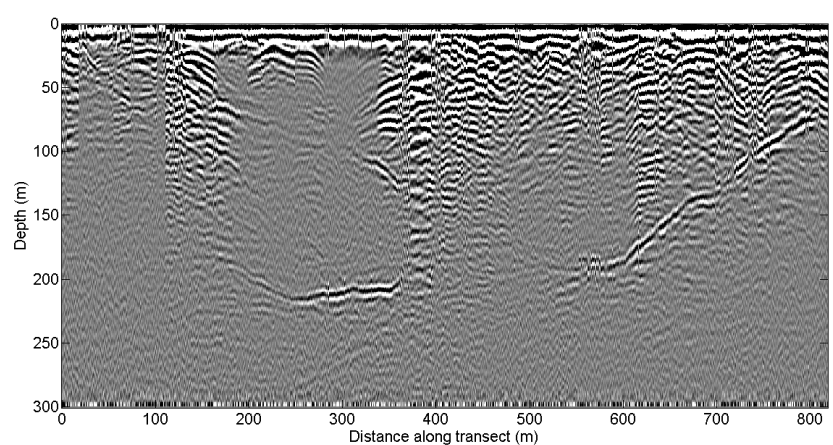

Figure 8. GPR transect across Imja-Lhotse Shar glacier from north to south on 25 September 2012 using a $10 \mathrm{MHz}$ antenna and velocity in ice of $167 \times 10^{6} \mathrm{~m} \mathrm{~s}^{-1}$.

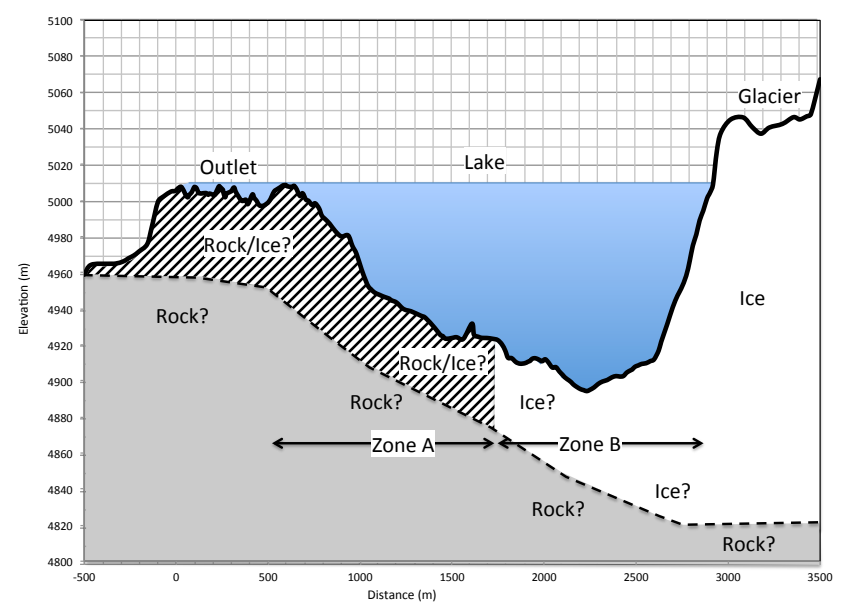

Figure 9. Conceptual model of Imja Tsho.

\subsection{Conceptual model of Imja Tsho}

Figure 9 shows a vertical cross section of a conceptual model of Imja Tsho created from the bathymetric and GPR survey data as well as a $5 \mathrm{~m}$ resolution digital elevation model (Lamsal et al., 2011) for the topography of the up-glacier area on the eastern end of the lake and the outside face of the moraine on the western end of the lake. The bottom of the Imja-Lhotse Shar glacier near the glacier terminus was determined from the GPR survey. The exact boundaries of the debris and ice areas and the lower bedrock and the glacier ice are unknown and shown as such in the figure using question marks (?). Similarly, the depth of mixed debris and ice in the western moraine end of the lake are mostly unknown. There is great difficulty in defining the boundary between the area of the lake underlain by ice as opposed to ice and rock or just rock. 


\section{Conclusions}

The results of a 2012 bathymetric survey of Imja Tsho show that the lake has deepened from $98 \mathrm{~m}$ in 2002 to $116.3 \pm 5.2 \mathrm{~m}$ in 2012. Likewise, the volume has increased from $35.8 \pm 0.7$ to $61.7 \pm 3.7$ million $\mathrm{m}^{3}$ over the past decade as well, a $70 \%$ increase. The lake volume is increasing at a rate of 2.51 million $\mathrm{m}^{3} \mathrm{yr}^{-1}$, and the average depth is increasing by $0.86 \mathrm{~m} \mathrm{yr}^{-1}$. Our survey results also suggest that the lake bottom has continued to lower as the ice beneath it has melted. Most of the expansion of the lake in recent years has been due to the retreat of the glacier terminus (eastern end of the lake) through calving processes. The rate of retreat of the glacier terminus, indicating the growth of the lake, has increased to $52.1 \mathrm{~m} \mathrm{yr}^{-1}$ over the last decade and the areal expansion rate has increased to $0.038 \mathrm{~km}^{2} \mathrm{yr}^{-1}$. The results of the GPR survey for the transect across the Imja-Lhotse Shar glacier show that the ice-bedrock interface is significantly below the lake bottom with an ice thickness over $200 \mathrm{~m}$ in the center of the glacier. The continued expansion of the lake has increased the maximum volume of water that could be drained from the lake in the event of a breach in the damming moraine to $34.1 \pm 1.08$ million $\mathrm{m}^{3}$, rather than 21 million $\mathrm{m}^{3}$ estimated in 2002 if the lake surface elevation decreases from 5010 to $4975 \mathrm{~m}$ (the elevation of the valley floor below the lake).

Acknowledgements. The authors acknowledge the support of the USAID Climate Change Resilient Development (CCRD) project, the Fulbright Foundation for the support of Somos-Valenzuela, and the National Geographic Society for their support of Byers. We also acknowledge the support of D. Regmi of Himalayan Research Expeditions for logistical support during fieldwork and D. Lamsal for providing us with a digital elevation model of the Imja Tsho and glacier area. The review comments of E. Berthier, K. Fujita, J. Ives, and A. Sakai are greatly appreciated, as are the comments of E. Byers and K. Voss.

Edited by: T. Bolch

\section{References}

Bajracharya, S. R. and Mool, P. K.: Glaciers, glacial lakes and glacial lake outburst floods in the Mount Everest region, Nepal, Ann. Glaciol., 50, 81-86, 2009.

Bajracharya, S. R., Mool, P. K., and Shrestha, B. R.: Impact of Climate Change on Himalayan Glaciers and Glacial Lakes: Case Studies on GLOF and Associated Hazards in Nepal and Bhutan, International Centre for Integrated Mountain Development (ICIMOD), Kathmandu, 2007.

Benn, D. I., Bolch, T., Hands, K., Gulley, J., Luckman, A., Nicholson, L. I., Quincey, D., Thompson, S., Toumi, R., and Wiseman, S.: Response of debris-covered glaciers in the Mount Everest region to recent warming, and implications for outburst flood hazards, Earth-Sci. Rev., 114, 156-174, 2012.
Biosonics, Inc. MX Series Specifications and Features, Seattle Washington 2012, http://www.biosonicsinc.com/ product-mx-habitat-echosounder.asp\#specsheet, last access: 16 July 2012

Bolch, T., Buchroithner, M. F., Peters, J., Baessler, M., and Bajracharya, S.: Identification of glacier motion and potentially dangerous glacial lakes in the Mt. Everest region/Nepal using spaceborne imagery, Nat. Hazards Earth Syst. Sci., 8, 13291340, doi:10.5194/nhess-8-1329-2008, 2008.

Bolch, T., Pieczonka, T., and Benn, D. I.: Multi-decadal mass loss of glaciers in the Everest area (Nepal Himalaya) derived from stereo imagery, The Cryosphere, 5, 349-358, doi:10.5194/tc-5349-2011, 2011.

Byers, A. C.: An assessment of contemporary glacier fluctuations in Nepal's Khumbu Himal using repeat photography, Himalayan Journal of Sciences, 4, 21-26, 2007.

Carrivick, J. L. and Rushmer, E. L.: Understanding high-magnitude outburst floods, Geology Today 22, 60-65, 2006.

Fujita, K., Sakai, A., Nuimura, T., Yamaguchi, S., and Sharma, R. R.: Recent changes in Imja Glacial Lake and its damming moraine in the Nepal Himalaya revealed by in situ surveys and multi-temporal ASTER imagery, Environ. Res. Lett., 4, 045205, doi:10.1088/1748-9326/4/4/045205, 2009.

Fujita, K., Sakai, A., Takenaka, S., Nuimura, T., Surazakov, A. B., Sawagaki, T., and Yamanokuchi, T.: Potential flood volume of Himalayan glacial lakes, Nat. Hazards Earth Syst. Sci., 13, 18271839, doi:10.5194/nhess-13-1827-2013, 2013.

Gades, A., Conway, H., and Nereson, N.: Radio echo-sounding through supraglacial debris on Lirung and Khumbu Glaciers, in: Nepal Himalayas, Proceedings of Debris-Covered Glaciers, edited by: Nakawo, M., Raymond, C. F., Fountain, A., IAHS Publ. no. 264, Seattle, 2000.

Gardelle, J., Arnauda, Y., and Berthier, E.: Contrasted evolution of glacial lakes along the Hindu Kush Himalaya mountain range between 1990 and 2009, Global Planet. Change, 75, 47-55, 2011.

Gardelle, J., Berthier, E., Arnaud, Y., and Kääb, A.: Region-wide glacier mass balances over the Pamir-Karakoram-Himalaya during 1999-2011, The Cryosphere, 7, 1263-1286, doi:10.5194/tc7-1263-2013, 2013.

Garmin: GPS 15xH/15xL Technical Specifications, 190-00266-03 Rev. A, Garmin International, Inc. Olathe, Kansas USA December, 2009.

Hagen, T., Dyrenfurth, G. O., von Fürer-Haimendorf, C., and Schneider, E. (Eds.): Mount Everest: Formation, Population and Exploration of the Everest Region, Oxford University Press, London, 1963.

Hambrey, M. J., Quincey, D. J., Glasser, N. F., Reynolds, J. M., Richardson, S. J., and Clemmens, S.: Sedimentological, geomorphological and dynamic context of debris-mantled glaciers, Mountain Everest (Sagarmatha) region, Nepal. Quaternary Science Reviews, 27, 2361-2389, 2008.

Hammond, J. E.: Glacial lakes in the Khumbu region, Nepal: An assessment of the hazards. Unpublished MA Thesis, University of Colorado, Boulder, CO, 1988.

ICIMOD-International Centre for Integrated Mountain Development: Glacial lakes and glacial lake outburst floods in Nepal, International Centre for Integrated Mountain Development (ICIMOD), Kathmandu, Nepal, 2011. 
Ives, J. D., Shrestha, R. B., and Mool, P. K.: Formation of glacial lakes in the Hindu Kush-Himalayas and GLOF risk assessment, International Centre for Integrated Mountain Development (ICIMOD), Kathmandu, 2010.

Jianchu, X., Shrestha, A., Vaidya, R., Eriksson, M., and Hewitt, K.: The Melting Himalayas: Regional Challenges and Local Impacts of Climate Change on Mountain Ecosystems and Livelihoods, ICIMOD Technical Paper, International Centre for Integrated Mountain Development (ICIMOD) Kathmandu, 2007.

Lamsal, D., Sawagaki, T., and Watanabe, T.: Digital Terrain Modelling Using Corona and ALOS PRISM Data to Investigate the Distal Part of Imja-Lhotse Shar glacier, Khumbu Himal, Nepal. J. Mt. Sci., 8, 390-402, 2011.

McFeeters, S.: The use of the normalized difference water index (NDWI) in the delineation of open water features, Int. J. Remote Sens., 17, 1425-1432, 1996.

Mool, P. K., Bajracharya, S. R., and Joshi, S. P.: Inventory of Glaciers, Glacial Lakes and Glacial Lake Outburst Floods: Monitoring and Early Warning Systems in the Hindu Kush-Himalayan Region, Nepal, International Centre for Integrated Mountain Development (ICIMOD), Kathmandu, 2001.

Nuimura, T., Fujita, K., Yamaguchi, S., and Sharma, R. R.: Elevation changes of glaciers revealed by multitemporal digital elevation models calibrated by GPS survey in the Khumbu region, Nepal Himalaya, 1992-2008, J. Glaciol., 58, 648-664, 2012.

Quincey, D. J., Richardson, S. D., Luckman, A., Lucas, R. M., Reynolds, J. M., Hambrey, M. J., and Glasser, N. F.: Early recognition of glacial lake hazards in the Himalaya using remote sensing datasets, Global Planet. Change, 56, 137-152, 2007.

Robertson, C. M., Benn, D. I., Brook, M. S., Fuller, I. C., and Holt, K. A.: Subaqueous calving margin morphology at Mueller, Hooker and Tasman glaciers in Aoraki/Mount Cook National Park, New Zealand, J. Glaciol., 58, 1037-1046, 2012.

Sakai, A., Fujita, K., and Yamada, T.: Volume change of Imja Tsho in the Nepal Himalayas, Disaster Mitigation and Water Management, 7-10 December ISDB 2003, Niigate, Japan, 2003.

Sakai, A., Fujita, K., and Yamada, T.: Expansion of the Imja glacier Lake in the East Nepal Himalaya, in: Glacier Caves and Glacial Karst in High Mountains and Polar Regions, edited by: Mavlyudov, B. R., 7th GLACKIPR Symposium, Institute of geography of the Russian Academy of Sciences, Moscow, 74-79, 2005
Sakai, A., Saito, M., Nishimura, K., Yamada, T., Iizuka, Y., Harada, K., Kobayashi, S., Fujita, K., and Gurung, C. B.: Topographical survey of end-moraine and dead ice area at the Imja Glacial Lake in 2001 and 2002, Bulletin of Glaciological Research, 24, 29-36, 2007.

Shrestha, A. B. and Aryal, R.: Climate change in Nepal and its impact on Himalayan glaciers, Regional Environmental Change, 11 (Suppl. 1), S65-S77, doi:10.1007/s10113-010-0174-9, 2011.

Sulzer, W. and Gspurning, J.: High mountain geodata as a crucial criterion of research: case studies from Khumbu Himal (Nepal) and Mount Aconcagua (Argentina), International Journal of Remote Sensing, 30, 1719-1736, 2009.

UNDP - United Nations Development Programme: Community Based Glacier Lake Outburst and Flood Risk Reduction in Nepal, Project Document, UNDP Environmental Finance Services, Kathmandu, Nepal, 2013.

USACE - United States Army Corps of Engineers: Uncertainty in Bathymetric Surveys, Coastal and Hydraulics Engineering Technical Note ERDC/CHL CHETN-IV-59, 2003.

Watanabe, T., Ives, J. D., and Hammond, J. E.: Rapid growth of a glacial lake in Khumbu Himal, Himalaya: prospects for a catastrophic flood, Mt. Res. Dev., 14, 329-340, 1994.

Watanabe, T., Kameyama, S., and Sato, T.: Imja-Lhotse Shar glacier dead-ice melt rates and changes in a supra-glacial lake, 19891994, Khumbu Himal, Nepal: Danger of lake drainage, Mt. Res Dev., 15, 293-300, 1995.

Watanabe, T., Lamsal, D., and Ives, J. D.: Evaluating the growth characteristics of a glacial lake and its degree of danger of outburst flooding: Imja-Lhotse Shar glacier, Khumbu Himal, Nepal, Norsk Geogr. Tidssk., 63, 255-267, 2009.

Yamada, T.: Glacier lakes and its outburst flood in the Nepal Himalaya, Monograph No.1, Data Centre for Glacier Research, Japanese Society of Snow and Ice, 1998.

Yamada, T. and Sharma, C. K.: Glacier Lakes and Outburst Floods in the Nepal Himalaya, in: Snow and Glacier Hydrology, Proc., Kathmandu Symposium, Nov. IAHS Publication No. 218, 1993. 